\title{
FACTORS OF ATTRACTIVENESS OF EDUCATION IN THE FIELD OF FINE AND DECORATIVE ARTS
}

\author{
Larysa Eivas \\ Kryvyi Rih State Pedagogical University, Ukraine \\ Yuliia Zenkovych \\ Kryvyi Rih State Pedagogical University, Ukraine \\ Daria Kudrenko \\ Kryvyi Rih State Pedagogical University, Ukraine
}

\begin{abstract}
The article dwells upon the problem of revealing ways to increase the attractiveness of education in the field of fine and decorative arts for today's youth. The specificity of "introducing" contemporary youth into the world of fine arts is studied, starting from the early stages (pre-school education) up to professional training. The factors affecting the decision of a person to choose a specialty in the field of art or education (artistic pedagogy) and the acquisition of corresponding professional qualifications are distinguished as follows: personal factor (abilities and talents of the individual), prestige as a motivational factor as well as information and organizational factors. The methodology of the study envisaged: systemic approach - in order to cover the problem consistently, systematically and holistically; an interdisciplinary approach to consider factors from the standpoint of pedagogy, psychology and sociology; historical approach - to estimate the state of formation of the system for future professional artist's training as well as fine arts teacher's training and decorative art tutor preparation. The scientific relevance of the research is the specification of the factors of attractiveness in terms of the choice of artistic or artistic-pedagogical specialty in the modern educational space. Generalization of the possibilities of vocational guidance of the educational system of teaching fine arts in its retrospective view (from the period of 1950-1991 to the beginning of the XXI century) is carried out. On the basis of the principal classification of the factors of choosing a profession and diagnosis results (questionnaires), certain recommendations are given in order to increase the attractiveness of education in the field of fine and decorative arts for both domestic and foreign students wishing to study in Ukraine.
\end{abstract}

Keywords: attractiveness of education, arts and crafts, educational process, fine arts, professional training, students.

\section{Introduction}

A great number of people feel a crave inside for this or that kind of activity in the field of art from time to time, while not all of them choose it as a calling in life and pursue their career in arts, in particular, fine or decorative-applied one, design, etc. 
Ukraine has long been famous for representatives who revealed their talent in pictorial, decorative and applied art. Now, that our country has dropped its position in terms of competitiveness in professional training in a number of areas (medical, natural science, physical and mathematical education, etc.), training of national specialists in the field of art and art pedagogy meets the world and European standards, and in many ways - has been successfully integrated into the global educational processes.

The up-to-date development of art and art-pedagogical education, the progress of culture and education on the national scale are conditioned by the national programs of Ukraine. The state programme "Education (Osvita (Ukraina XXI stolittya), 1994) sets the artistic and aesthetic education as one of the main directions of youth education, which includes the development of abilities to multiply the cultural and artistic wealth of the nation. Along with the declaration of constitutional right of citizens for education in all its forms and at all its levels, the Law of Ukraine "On Education" (article 21, parts 1 and 2) stresses the creation of conditions for receiving the specialized education, in particular the artistic one (Pro osvitu, 2017). In February 2021, draft amendments to the Law of Ukraine "On Culture" (Pro kulturu, 2010), were adopted as the basis. Article 4, paragraph 1 , of the draft law sets the development of art education as the state policy priority in the sphere of culture.

Right now, domestic scholars are pondering the questions related to increasing the attractiveness of arts education for both domestic and international students. So, in this article, we are also trying to comment on this issue.

\section{Theoretical Substantiation of the Problem}

Certain comparative aspects of professional education in the country and abroad are covered in the works of V. Hamanyuk (Hamanyuk, 2012), T. Koshmanova (Koshmanova, 2002), E. Lokshyna (Lokshyna, 2013) and others. The top enquiry into professional-pedagogical and art-comparative studies is caused by the traditional interest of the Ukrainian community in foreign achievements, approval in the minds of the general public of the national system of professional training development in unity and integration with the world's ongoing achievements.

In fact, art education components of Vocational Education are presented in the works of numerous Slavic scholars (Arapova, 2004; Otich, 2011; Orlov, 2003; Pichkur, 2000; Stukalova, 2011). These scholars have detailed the nature and content of the professional training of future specialists in the field of fine arts, and have made valuable recommendations on ways of mapping professional and future artists’ skills. 
The following artists-pedagogues (Nemensky, 1987; Rostovtsev, 1998; Shmagalo, 2005; Yusov, 2002) speak about their common features with artpedagogical education through their critical understanding of the principles of specialists' training in the field of Arts (fine arts and decorative-applied). As practice shows, this relieves some of the strain in applicants' choice between the arts and education to obtain a basic specialty in the field of fine and decorative arts.

According to the basic classification of E. Klymov (Klymov, 2004), among the factors that determine the choice of profession are the following: a formed system of value representations of the individual, professional self-determination from the positions of parents, friends, teachers, age, gender and medical problems, socio-economic aspects, awareness of the profession value in society, the level of personal qualities and aspirations, prestige of the profession, interests, abilities of the personality, etc.

We can also claim the works of foreign researchers are of high interest for this and further research concerning: ways to invest key competences in learning at all stages of life (Rychen, 2003), social career context (Herr, 2008), choosing career guidance strategies for people of different cultures in the United States (Leung, 2008) and others.

At present, we have a gap between the theoretical developments that have been made in the process of improving the methodological, practical components of professional training of student youth in the arts, and the real conditions that would promote the national system of training professionals in the field of fine arts and decorative arts.

Therefore, the aim of our study is to present the changes in the educational system for training an artist, artist-educator (since the second half of the twentieth century) in comparison with the modern system of gradual training in the field of fine and decorative arts and on this basis, to highlight and analyse the factors that can decisively influence the attractiveness of such education and its popularisation. The question is debatable - which really makes this education attractive to today's youth.

\section{Methods of the Research}

According to the objectives of the research, the following methods were applied: general scientific methods - study and analysis of scientific literature on psychology and pedagogy, works of domestic and foreign authors in the field of art pedagogy; specifically scientific methods: structural and logical - in order to present a model of a multilevel system of art and art-pedagogical education from the period of 1950-1991 and up to the beginning of the XXI century; comparison and interpretation - to identify and analyse the factors that, in our opinion, shape 
the popularity of education in the field of fine and decorative arts; prognostic allows one to formulate recommendations aimed at increasing the level of attractiveness of education in the field of fine arts and decorative arts at the level of professional training in higher education institutions. The empirical method (questionnaire) was applied to study the rating of motives for students' professional choice of Art and Graphics department of the Art faculty in Kryvyi Rih State Pedagogical University when entering the specialty Fine Arts and Design. The training itself is viewed as a structure at which different levels of career guidance are exercised.

We are analysing this problem consistently by:

a) comparing the vocational/professional guidance of the educational system in retrospect (1950-1991) with the modern system of gradual training of a specialist in fine, decorative art, design, teacher or head of the circle; carrying out analysis on the formation of attractiveness of art and art-pedagogical education at its educational levels;

b) distinguishing the factors influencing the formation of motivation to choose a profession of artistic and artistic-pedagogical direction;

c) on the basis of the conducted research, offering recommendations aimed at increasing the level of attractiveness of education in the field of fine and decorative arts.

\section{Results of the Research}

In our study, we focus on the average young man or woman, for whom, as a rule, acquaintance with the arts begins in the family circle and in the institutions they visited during the preschool and school stages of their life. Here is a note: in Ukraine there is a consistent system of human aesthetic development, the early fostering of the ability to perceive and understand works of art. Educational programs of state preschool educational institutions contain such important components as demonstration and description of reproductions of paintings by famous domestic and foreign artists. The technique of speech development of preschool-aged children by means of fine arts is developed, there are numerous researches and recommendations which include classical works and what sequence to choose to acquaint children with them (questions on the content of canvases, characters depicted, making up a common story, etc.), how to make a picture description.

Practically, domestic training of the future professional artist, teacher of fine arts, teacher of decorative art was shaped in the Soviet times, and was carried out in specialized art schools and studios, in circles of decorative and applied direction, forming a prolonged attractiveness of education in the field of fine arts. 
For example, in the period of 1950-1991 as a complete system, it was a vertical structure with a career-oriented influence at different stages:

1. General education institutions: elementary level (Grades 1-3) manual labor, artistic work, fine arts; secondary level (5-6th grades) labor training, fine arts; high level (Grades 9-10) - industrial training, vocational training, artistic and service work; classes with advanced study of fine and folk art; electives, circles.

2. Out-of-school educational establishments: children's art schools; palaces and houses of pioneers; stations of young technicians.

3. Specialized secondary schools: vocational schools of artistic profile; art schools; pedagogical schools.

4. Higher education institutions: academies of arts; art institutes; pedagogical institutes (faculties of graphic arts, industrial-pedagogical faculties).

5. Postgraduate education: faculties of advanced training, courses; training institutes.

6. Complexes and educational associations: «schools - vocational schools - production»; «Pedagogical classes - pedagogical schools pedagogical institutes - advanced training courses»; «Art schools - folk crafts - art institutes» (Eivas, 2017).

Having absorbed the best of the previous period, the model of modern Ukrainian education in the field of art and art pedagogy is subordinated to the ranking of the basic level training: elementary, primary, secondary and higher professional.

At the same time, new elements of the educational system are emerging from the period of Ukraine's independent statehood up to the beginning of the 21st century, which promote the choice of the artistic and artistic-pedagogical specialty, among the following:

1. Comprehensive secondary educational institutions: specialized secondary schools; private schools; lyceums, gymnasiums of aesthetic profile; colleges; children's aesthetics academies.

2. Out-of-school educational institutions: Minor Academy of Sciences; flexible system of formal and informal extracurricular education; museums, exhibitions, competitions; art projects.

3. Specialized secondary educational establishments: colleges of arts, vocational colleges, institutes of arts; teachers' training colleges; art institutes, colleges; colleges of arts, design and arts and crafts.

4. Higher education institutions: institutes of arts; academies and universities of national importance; exchange programs between domestic and foreign higher education institutions; grant programs.

5. Postgraduate education: internships, workshops; training programs. 
6. Centres and educational associations: «pedagogical class pedagogical college - institution of higher pedagogical education; «Postgraduate Pedagogical Education Institution - Formal and Nonformal Teacher Education»; «Art schools and centres - art colleges art-pedagogical and technological-pedagogical HEI»; «Postgraduate education institutions - formal and non-formal art education» (Eivas, 2017).

Under the influence of cultural, historical, scientific and technological progress and political changes in the formation of independent statehood, in present day Ukraine, there is a process of reviewing of folk arts and crafts role and place in general secondary education, the material and technical basis for such education is being increased, experience and teaching methods are being accumulated, introducing new techniques and technologies that are passed on to talented youth and orienting them to the choice of profession in artistic and artistic-pedagogical direction, which can be considered as one of the basic factors of art education attractiveness.

For example, let us provide an example of professional orientation and promotion of future education in the field of fine and decorative arts applied at the level of elementary stage of secondary school education. During the Drawing lessons, the basic varieties of Ukrainian traditional decorative and applied art are introduced. Drawing lessons for six- to seven-year-old students involve not only getting acquainted with Petrykivka, Opishniansky, Kosiv and other paintings (examining dishes, analysing the components of patterns, etc.), but also reproducing the elements of these paintings themselves. Under the guidance of the teacher, children paint paper templates or a raw form of wood or ceramics, have the opportunity to depict vegetable (flowers, petals, shoots), geometric traditional elements by the types of arts and crafts, to understand the practical expediency of such products, to gradually become aware of the unique national mentality and get their first reflections on their future profession.

The school period makes it possible to diversify the children's and adolescents' ideas about the varieties of fine and decorative arts, to immerse themselves gradually into the specifics of each of them.

In addition to the Art discipline at school, which is taught to high school students and aimed to enrich the younger adolescents' understanding of the main arts in historical and cognitive perspectives, the content of all disciplines of the humanitarian cycle (the Ukrainian language and literature, World literature, Ukrainian and World history, geography) is diverse with the information somehow related to the study of arts. It is worth noting, we do not find any similar integration, consistency, clarity and thoughtfulness of the educational information submission into the syllabus studied by students of the relevant age from the European Union countries. Numerous reproductions of famous masters' pictures 
on textbook and manual pages, photographs and QR codes that open up video content enrich students' consciousness, interest and tune them into the excellence of fine art world. For example, a textbook in World literature for the tenth grade of general secondary education institutions (Kadobianskaya \& Udovichenko, 2018) contains images of Rafael frescoes, reproductions of paintings by John William Waterhouse, Herbert-James Draper, Jan Jordan, Thomas Wilmer Dewing, Maurice Danny and other prominent artists. The works of the world recognized writers, prose plots and poetic works are illustrated through paintings and graphics. On the other hand, the textbooks and manuals in the Ukrainian language are mostly illustrated by the stylization of the Petrikivka paintings. Apparently, such information serves as additional motivation, and partly a decisive impetus to test their skills in the artistic field.

The next step in exploring of attractiveness of education in the field of fine arts and crafts is the specification of the factors that influence today's youth to choose fine arts and crafts as their profession or vocation.

In order to find out the rating of the factors and to identify the main motivators of modern youth to enter the study in arts and pedagogical and artistic specialties, a pilot survey was conducted by means of a questionnaire. Hence, 25 first-year students majoring in Secondary Education (Fine Arts) and 30 students of the specialty Design were selected for the diagnostics. The students were asked to answer the question "What circumstances and to what extent influenced your choice of profession as a fine arts teacher / head of the decorative arts club / designer?” The questionnaire contained some judgments, the degree of agreement to which allowed us to determine the rating of factors influencing the choice of future profession. The respondents were asked to choose from three levels of assessment: "predominant", "average", "completely unaffected" and mark the corresponding grade level with a "+” sign in each answer line.

The survey consisted of the questions with one choice by the level of influence (one answer for each question): 1. Family traditions; 2. Tips from friends and acquaintances; 3. Parents' recommendations; 4. Teachers' recommendations; 5. I want to do creative work; 6. I am good at drawing / decorative creativity / design; 7. Random choice of profession; 8. I want to manage children's creativity in the field of fine arts / decorative arts / design; 9. I want to do teaching; 10 . The future of the profession gives prospects for career advancement; 11. I am well-informed by the mass media about the demand for this profession in the labor market; 12. I consider the profession prestigious. 


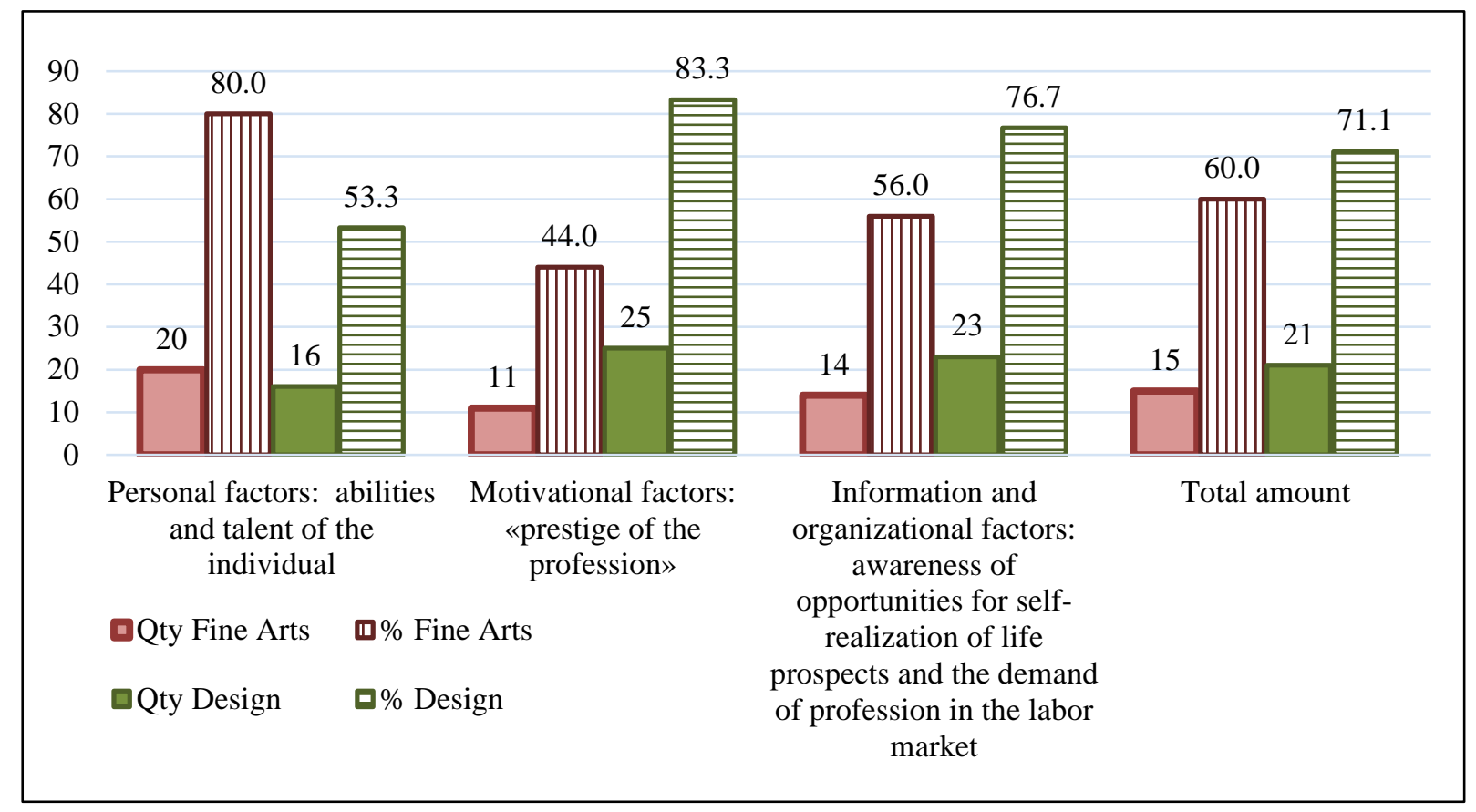

Figure 1 Rating of the Factors of Education Attractiveness in the Field of Art-pedagogical Training and Art Education

The qualitative analysis showed that in the ranking of factors of education attractiveness in the field of fine and decorative arts, the following factors are predominating: personal, motivational, informational and organizational. In general, $60 \%$ of students of arts and pedagogical specialty (Secondary education. Fine arts) and $71.1 \%$ of students of the educational branch of Arts (Design) made the choice in favour of these factors. We have conditionally distinguished the education attractiveness factors in the field of fine arts and arts in three groups (see Fig. 1).

Personal factors. This group of factors is related to the individual creative abilities of the personality, which is reinforced by the desire to express oneself in art, the desire for self-expression, following the traditions of art and at the same time, the search for one's self, artist's, artist-teacher's, demonstration of one's own identity. If a young person has the opportunity to observe the work of well-known masters of fine arts (excursions to artists' workshops, ethnographic museums, etc.), fascinated by the personal and professional traits of contemporary art, then the motivational positive background for choosing a future profession is due to be created quite quickly.

The key factor in fine arts teaching is the individual's ability and talent. There is no definite sensitive period for the development of fine arts. This period can be considered childhood, adolescence, youth; and the flourishing of fine arts talent can also fall into maturity or even old age. Raphael created his best paintings in 
the period of nineteen to thirty years old; while the genius of I. Repin still did not fade after he turned 70 being quite elderly according to the general physiological estimation. In the world of contemporary art, we have examples where a person reveals his or her talent, whether in an old or elderly age. It is no coincidence that various educational services offered at home by foreign offices of formal and informal education provide educational services at the levels of pre-professional, vocational, higher, and postgraduate education. Numerous preparatory and preliminary programs, courses, training in boarding schools or specialized schools are also offered.

However, in our field of research, there are young people we are focused on, who are only choosing their professional careers. That is why the second group motivational factors, is united and illustrated by the phrase "prestige of the profession". Considerations regarding the prestige of the future profession are brought to the foreground precisely at a young age. Being known and popular is a dominant incentive for a young person to choose an art profession. It is unlikely that older adolescents or young men have a clear idea of the difficulties that the daily, often routine, work of an artist involves. And it is the art faculties that are traditionally considered the most "diffuse" in terms of preserving the student contingent. It is quite natural that a young man tries to test himself in various fields.

For many people, the common pattern of choosing a profession right after schooling is definitely in the past. Today, studying and retraining, getting several professions is a common occurrence, and not only school graduates can be observed as fine arts students for which fine and decorative arts are the basis for further professional improvement in various related fields: design of clothes, industrial design, architecture and construction, etc.

Evidently, expectations for career growth is not the last factor in present-day understanding of the profession prestige (teaching in the field of art, management of art projects, art museums, exhibition halls, expert examination of works of art, obtaining honorary scientific and artistic titles, etc.), the opportunity to receive high financial support for creating art works, travel around the country and the world during plein air (artist-painter, graphic artist, artist of applied arts), or work online with Ukrainian and foreign customers (designer).

Becoming famous through the artist's elaborate manner of painting or graphics, mastering sophisticated traditional decorative art techniques, successful design activities, educating a student - a future artist who will continue his teacher's work in his paintings - are the motives for choosing it as their future profession. At the same time, the efforts of the artist, the painter to preserve and restore the monuments of art, to cherish the traditions of the national cultural heritage and to interpret them in contemporary art, also "work" for the prestige of the artist's profession. Therefore, striving to make your name known through your 
chosen profession is an ambitious desire and a motivated choice that parents and teachers should support in every way, cultivating reasonable ambition, while encouraging young people to work hard, for cultural and professional growth.

Information and organizational factors. The ability to quickly and freely receive information related to the ways and methods of desirable training is a significant advantage in realizing your educational intentions in the age of mass communications and the Internet. In the nineteenth century, regardless of any social origin, there was one path for talented and gifted young men - in the field of the visual arts - the Academy of Arts, where the brilliant artists of the past were shaped and taught. In today's conditions, finding "your teacher", your manner, sticking to a known stream is a big problem, sometimes because of information overflow and a variety of ways. Therefore, "searching for yourself", a professional direction, own style in art - is responsible, and sometimes a long and painful process. In this sense, a systematic and accessible presentation of information useful to applicants and people interested in the visual arts is the primary task of educational institutions.

Moreover, the visualization of educational offers by means of infographics, image-oriented professional products, advertising of specialties along with the information about artists working within the walls of an educational institution, detailed information about the offered educational programs (their licensing and accreditation, content) are crucial elements; virtual museum of exhibitions (domestic and foreign), announcements and archives of cultural and artistic events; availability of budget places for students, tuition fees and options for simplification of payment in a convenient for students way (per semester or month, at the end of the academic year), guarantee of receiving a scholarship for academic progress in a proper amount, the possibility of receiving personal grants, - this is not a complete list of organizational measures to be taken in order to increase the attractiveness of gaining education in the field of fine arts and decorative-applied arts.

The possibility of self-realization of life prospects and the demand of the profession in the labour market is a significant factor that attracts applicants when entering a certain educational institution. Therefore, the specification of places of employment, career prospects, cooperation of the structure with various institutions, foundations, establishments, art associations that are in need of such specialists - such information is attractive, informative and organizationally grounded.

The aforementioned factors allow putting forward certain recommendations aimed at increasing the attractiveness of education in the field of fine arts and crafts at the level of professional training in higher education institutions:

a) clear organization of the educational process. Students from the first hours of attending higher education establishment should not be "lost" in the flow of 
information and in the new activities they are mastering. Reviewing classrooms and workshops, learning the schedule and being able to properly understand the information it contains, providing information about the types of practices, materials and equipment you need to work - these and other activities should always be used in working with the freshmen. The precise and clear organization of the educational process stimulates the further desire to study, attend lectures and seminars both on the direct profile of training and those related to other cycles of study. The assessments of the institution's reputation, the relevance of the educational offerings to the educational reality, and the feedback on social networks about the benefits or disadvantages of education also affect the attractiveness or distrust to education.

b) Involvement of renowned artists, painters and promising young people in teaching in higher education institutions of artistic direction. Even though artistic genius is sometimes not combined with a teaching talent or pedagogical ability, we still have examples of a combination of both creative and teaching talents. For example, the well-known Ukrainian artist T. Yablonskaya has combined fruitful artistic work and teaching at Kyiv State Art Institute for more than a decade. A pedagogical talent was also characteristic to a Ukrainian painter I. Padalka, who worked at Kharkov Art and Industrial Institute and Kiev Art Institute. The combination of many years of successful experience of practical work in painting, graphics, arts and crafts, etc. and teaching skills in pedagogical activity - an inexhaustible source of attractiveness of art, motivation for future students to study it.

c) Diversification of education forms in art institutions. Lecture and seminar forms of education, which have been dominant for higher education institutions since the European Middle Ages and the emergence of the first European universities of the modern shape, should not be dogmatically reproduced in educational institutions of artistic direction. According to our observations, for students of the faculties of higher educational establishments of art education and faculties of arts in institutions of higher pedagogical education it is necessary to diversify the forms of educational work, using individual academic work in a more active way, performing copy tasks in museums, performing 3D-tasks in museums of virtual tours: The Apple Virtual Museum, Google Art Project, and later Google Arts \& Culture, a digital project called Museum of the World, catalogues of digitized works of art by the Louvre Museum, Metropolitan, the Solomon Guggenheim museum complex in the Vatican). The control and monitoring over the level of knowledge mastering in certain disciplines, which are not directly related to the future art profession, can take place remotely. In most training disciplines, it is also advisable to allow an external form of summary reporting (obtaining credits in accordance with the individual training schedule at a convenient time for students). 
d) Individual support for the student's learning process (especially foreign students): curatorial activity itself is an outdated form of interaction between the teachers and students. The tutoring system, distributed in the UK educational establishments, in which one teacher interacts with a subset of 7 to 8 students, is entirely and fully suited for art faculties. Thus, educational interaction of students with teachers who provide a certain master class, students' independent work, terms and forms of mastering non-core disciplines, features of dormitory accommodation, public aspects of students' life, etc. - all these issues are to be dealt with the tutor who is aware of the peculiarities of students' educational and cognitive activities, as well as of the personal characteristics of each.

\section{Conclusions}

The conducted research on the problem of revealing ways to increase the attractiveness of education in the field of fine and decorative arts for contemporary youth has allowed us to draw such conclusions as well as present the following outcomes:

1. Comparison of professional guidance of the educational system in the retrospective view of the modern system of gradual training of a specialist in fine and decorative art, design, a teacher or a head of the circle has allowed noting the emergence of new elements in the educational system that promote the choice of artistic or artisticpedagogical profile (lyceums, gymnasiums/grammar schools of aesthetic profile, collegiums, children's academies of aesthetic profile, etc.); the fact of the emergence of a flexible system of formal and informal extracurricular out-of-school education forms, museums, exhibitions, competitions, participation of schoolchildren in art projects; the rise in the emergence of vocational art colleges, art institutes, higher colleges of art, design, arts and crafts, institutes of arts; academies and universities of national importance, exchange programs between domestic and foreign higher education institutions, grant and charity programs; internships, workshops, training programs, new forms of postgraduate education.

2. There have been analysed the possible ways of forming attractiveness of art and art-pedagogical education at separate educational levels.

3. The pilot study realised by means of questionnaire survey of students in art-pedagogical (Secondary education. Fine arts) and art (Design) specialties has enabled us to diagnose the motives influencing a young person in taking his or her decision to pursue a career in creative profession and to obtain the appropriate profession; the pilot study has also allowed us to choose the highest by rating of influence factors, 
namely: personal - abilities and talent of the individual, motivational factors, in particular - "prestige of the profession", information and organizational factors (awareness of opportunities for self-realization of life prospects and the demand of profession in the labour market). The attractiveness of the highlighted factors - $71.1 \%$ for students of the specialty "Design" in comparison with the choice of students of a pedagogical specialty "Fine Arts" (61.0\%) prevails by 11\% for future artists-designers. The comparatively lower choice of respondents future teachers of the statements "I want to do teaching", "The future profession gives prospects for career growth" or "I consider the profession prestigious" is caused by insufficiently high prestige of the modern teaching profession in Ukraine.

4. There are recommendations given for their implementation, which, in our opinion, will definitely stimulate an increase in the level of attractiveness of education in the field of fine and decorative arts.

The carried-out study does not exhaust the laid-out problem, it still remains quite debatable and requires further scientific research on specifying new forms and methods in order to increase the motivational choice of education in the field of fine and decorative art at all its levels along with their methodological substantiation demand.

\section{References}

Arapova, S. (2004). Obuchenye yzobrazytelnomu yskusstvu. Yntehratsyia khudozhestvennoho y lohycheskoho. SPb: KARO, 2004.

Eivas, L. (2017). Rozvytok systemy pidhotovky vchyteliv dekoratyvno-prykladnoho mystetstva (druha polovyna XX - pochatok XXI stolittia): dys. ...kand. ped. nauk: 13.00.01. Khmelnytskyi.

Derzhavna natsionalna prohrama «Osvita» («Ukraina XXI stolittia»). (1993). Retrived from http://zakon0.rada.gov.ua/laws/show/896-93-\%D0\%BF.

Hamaniuk, V. (2012). Inshomovna osvita Nimechchyny u konteksti zahalnoievropeiskykh intehratsiinykh protsesiv: teoriia i praktyka: monohrafiia. Kryvyi Rih: Vydavnychyi dim.

Herr, E. L. (2008). Social Contexts for Career Guidance Throughout the World. International Handbook of Career Guidance, 45-69. Retrieved from https://link.springer.com/ chapter/10.1007/978-1-4020-6230-8_3.

Kadobianska, N. \& Udovychenko, L. (2018). Zarubizhna literatura: pidruchnyk dlia 10 klasu zakladiv zahalnoi serednoi osvity. (Riven standartu). Kharkiv: Sytsyia. Retrieved from https://pidruchnyk.com.ua/uploads/book/10-klas-zarubizhna-literatura-kadobjanska2018.pdf

Klymov, E. (2004). Psykholohyia professyonalnoho samoopredelenyia. Moskva: Academia.

Koshmanova, T. (2002). Rozvytok pedahohichnoi osvity u SShA (1960 - 2000 rr.): dys. ... d-ra ped. nauk: 13.00.04. Kyiv.

Leung, S. A. (2008). The Big Five Career Theories. International Handbook of Career 
Eivas et al., 2021. Factors of Attractiveness of Education in the Field of Fine and Decorative Arts

Guidance, 115-132. Retrieved from https://link.springer.com/chapter/10.1007/978-14020-6230-8_6.

Lokshyna, O. (2013). «Pedahohichna komparatyvistyka - 2013»: metodolohichne fokusuvannia ukrainskykh doslidnykiv z porivnialnoi pedahohiky. Pedahohichna komparatyvistyka - 2013: transformatsii v osviti zarubizhzhia ta ukrainskyi kontekst. Kyiv: Pedahohichna dumka. 10-11.

Nemenskyi, B. (1987). Mudrost krasoti. O problemakh estetycheskoho vospytanyia. Moskva: Prosveshchenye.

Orlov, V. (2003). Profesiine stanovlennia vchyteliv mystetskykh dystsyplin. Kyiv: Naukova dumka.

Otych, O. (2011). Rozvytok tvorchoi indyvidualnosti studentiv profesiino-pedahohichnykh navchalnykh zakladiv zasobamy mystetstva: monohrafiia. Chernivtsi : Zelena Bukovyna.

Pichkur, M. (2000). Formuvannia profesiinoi kultury maibutnoho vchytelia obrazotvorchoho mystetstva (na materiali kompozytsii): avtoref. ...dys. kand. ped. nauk: 13.00.04. Kyiv.

Rostovtsev, N. (1980). Metodyka prepodavanyia yzobrazytelnoho yskusstva v shkole. Moscow: Prosveshcheniye.

Rychen, D. S. \& Salganik, L. H. (Eds) (2003). Key Competencies for a Successful Life and a Well-Functioning Society. Germany: Hogrefe and Huber Publishers.

Shmahalo, R. (2005). Mystetska osvita v Ukraini seredyny XIX - seredyny XX st. (strukturuvannia, metodolohiia, khudozhni pozytsii). Lviv: Ukrainski tekhnolohii.

Stukalova, O. (2011). Visshee professyonalnoe obrazovanye $v$ sfere kulturi y yskusstva: sovremennoe sostoianye y perspektyvi razvytyia: avtoref. dys. ... d-ra ped. nauk: 13.00.08. Moskva.

Yusov, B. (2002). Yzobrazytelnoe yskusstvo y detskoe yzobrazytelnoe tvorchestvo. Ocherky po ystoryy, teoryy y psykholohyy khudozhestvennoho vospytanyia detei. Mahnytohorsk: Mahnytohorskyi hosudarstvennii unyversytet.

Zakon Ukrainy. (2011). №2145-VIII vid 14.12.2011 r. «Pro kulturu». [Elektronnii resurs] / Rezhym dostupu: Poshukova systema: «Verkhovna rada Ukrainy: Zakonodavstvo». Retrieved from https://zakon.rada.gov.ua/laws/show/2778-17\#Text

Zakon Ukrainy. (2017). №2145-VIII vid 05.09.2017 r. «Pro osvitu». [Elektronnii resurs] / Rezhym dostupu: Poshukova systema: «Verkhovna rada Ukrainy: Zakonodavstvo». Retrieved from https://zakon.rada.gov.ua/laws/show/2145-19\#Text 